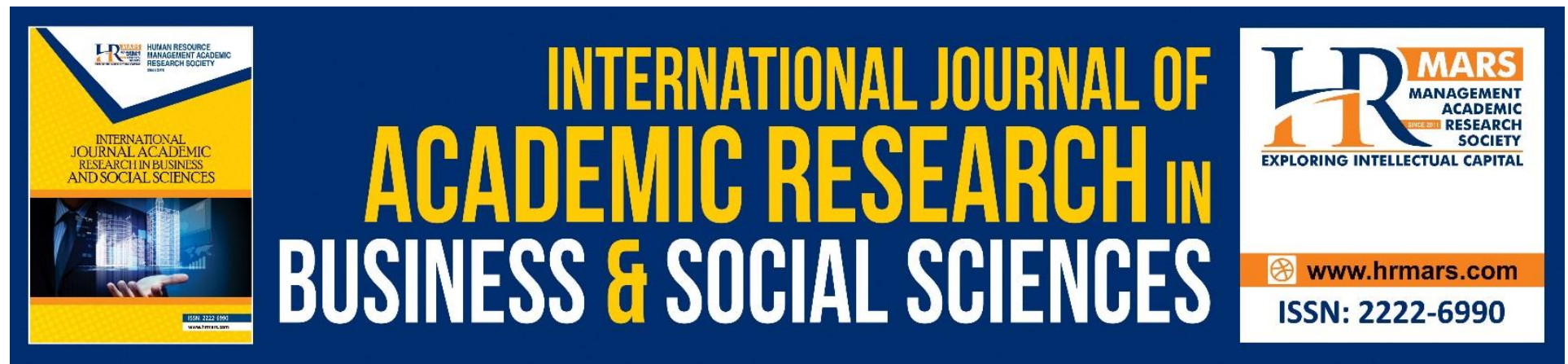

\title{
Analysis of the Relationship between World Oil Price and Exchange Rate on Agricultural Commodity Prices in Indonesia
}

Cut Endang Kurniasih, Hizir, Muhammad Nasir, Mohd Sadad Mahmud, Norfadzilah Rashid, Puspa Liza Ghazali, Asyraf Afthanorhan

To Link this Article: http://dx.doi.org/10.6007/IJARBSS/v8-i12/5055 DOI: 10.6007/IJARBSS/v8-i12/5055

Received: 22 Oct 2018, Revised: 28 Nov 2018, Accepted: 28 Dec 2018

Published Online: 29 Dec 2018

In-Text Citation: (Kurniasih et al., 2018)

To Cite this Article: Kurniasih, C. E., Hizir, Nasir, M., Mahmud, M. S., Rashid, N., Ghazali, P. L., \& Afthanorhan, A. (2018). Analysis of the Relationship between World Oil Price and Exchange Rate on Agricultural Commodity Prices in Indonesia. International Journal of Academic Research in Business and Social Sciences, 8(12), 561576.

\section{Copyright: (C) 2018 The Author(s)}

Published by Human Resource Management Academic Research Society (www.hrmars.com)

This article is published under the Creative Commons Attribution (CC BY 4.0) license. Anyone may reproduce, distribute, translate and create derivative works of this article (for both commercial and non-commercial purposes), subject to full attribution to the original publication and authors. The full terms of this license may be seen at: http://creativecommons.org/licences/by/4.0/legalcode

Vol. 8, No. 12, 2018, Pg. 561 - 576

Full Terms \& Conditions of access and use can be found at http://hrmars.com/index.php/pages/detail/publication-ethics 


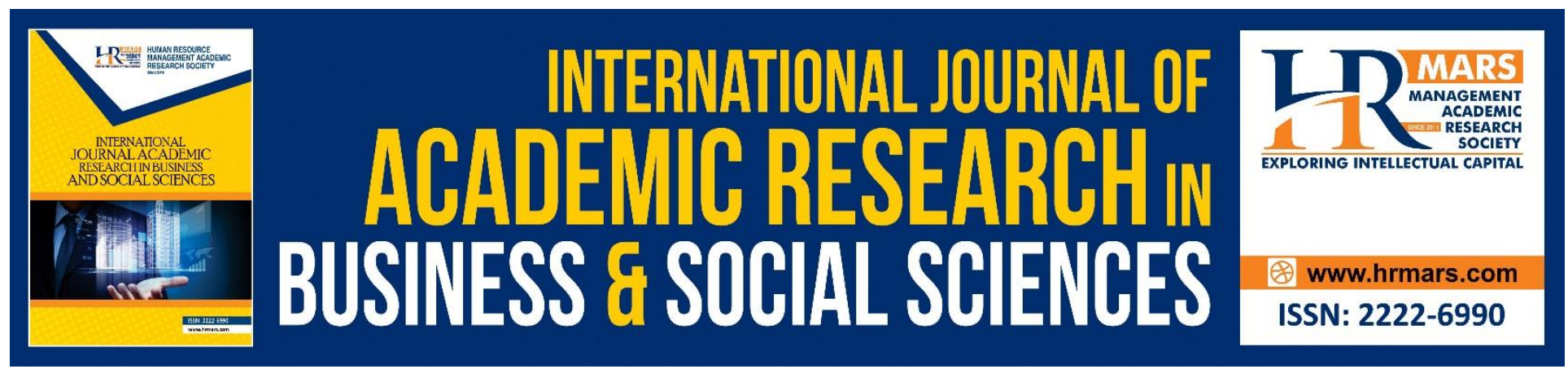

\title{
Analysis of the Relationship between World Oil Price and Exchange Rate on Agricultural Commodity Prices in Indonesia
}

\author{
Cut Endang Kurniasih ${ }^{1}$, Hizir², Muhammad Nasir ${ }^{3}$, Mohd Sadad \\ Mahmud $^{4}$, Norfadzilah Rashid ${ }^{5}$, Puspa Liza Ghazali 6 , Asyraf \\ Afthanorhan $^{7}$ \\ 123 Faculty of Economics and Business of Syiah Kuala University \\ ${ }^{4,5,6}$ Faculty of Economics and Management Sciences, University Sultan Zainal Abidin \\ Corresponding Author: mohdsadad@unisza.edu.my
}

\begin{abstract}
Increasing food prices in the world caused a global food crisis. Some Asian countries are also affected by rising world food prices, including Indonesia. Using Vector Error Correction Model (VECM) method, the researchers intend to analyze the long-term relationship between world oil price and exchange rate to agricultural commodity price (rice, corn and soybean) in Indonesia and test whether there is an existing causality. This analysis is based upon the data set covering the monthly period of January 2010 to June 2017. The empirical results show that there is a longterm equilibrium relationship between world oil prices and exchange rate against three of agricultural commodity prices and there is only unindirectional causality of the world oil price against rice price. Nevertheless, this study confirms the hypothesis from world oil price to agricultural commodity price. While exchange rate did not show the pattern of causality relationship either one or two direction to each agricultural commodity price under study. According to Impulse Response Function (IRF), the study results show that the rice price negatively responds to shock of world oil prices in the short term while responding positively to shock of world oil prices in the long term. But response of corn and soybean prices is not significant. Meanwhile, shock of exchange rate is responded positively by rice and soybean prices. Conversely, shock of exchange rate on corn prices shows relatively weak and negative responses. To controlling surging prices of agricultural commodities (food), it is suggested that government policies directed at stabilizing food prices policies and exchange rate and also anticipate the exogenous impact of changes in world oil prices that could affect rice price.
\end{abstract}

Keywords: World Oil Price, Exchange Rate, Agricultural Commodity Price, VECM, Granger Causality, Cointegration IRF, FEVD 


\section{INTRODUCTION}

In the last few years the international world and including Indonesia are facing key issues discussed in Sustainable Development Goals (SDGs) such as poverty; hunger; public health; education; gender equality; clean water and sanitation; energy; decent work and economic growth; industry, innovation and infrastructure; inequality; sustainable cities and communities; consumption and production; climate change; marine resources; terrestrial ecosystems; peace, justice and effective institutions; and global partnerships. But in the middle of 17 of those issues, hunger remains a serious problem for Indonesia because there are still 19.4 million people suffering from hunger (FAO, 2015: 46).

Indonesia as an agricultural country with the agricultural sector plays a strategic role in the provision of food to provide the nutritional needs of 245 million Indonesians and empirically able to reduce food crisis (Ministry of Commerce, 2016). The availability of supply and demand for food commodities should be considered in meeting basic human needs. However, the availability of food and agricultural commodities is greatly affected by disturbances in both natural conditions in climate, limitation and conversion of agricultural land and international geopolitical conditions. This will result in disruption of agricultural commodity supply (Sujai, 2011). In addition, the length of marketing chain in commodity distribution causes inefficiency. That means the delay in food fulfillment can trigger rising food prices so will be difficult to control the price and finally causing decline in public welfare (Nurhemi, 2014).

Based on Food and Agriculture Organization (FAO) data, the world Food Price Index has increased from 2000 to 2014. The rise in food prices in the world caused a global food crisis. Some Asian countries are also affected by rising world food prices. This is reflected in food price index in Indonesia, Malaysia, Singapore and Thailand which increased from 2000-2014. Singapore has the lowest food price index compared to other countries. In contrast, Indonesia has the highest food price index which reached 6.73 points.

The three key determinants of the spike on agricultural commodity prices according to Abbott et al. (in Nazlioglu and Soytas, 2011) are excess demand, the value of US dollar (exchange rate), and the energy-agriculture linkage. Dancy (in Aye, 2016) stated that food prices can reflect oil price. It is caused by modern agriculture to produce food commodities using oil. Crude oil is an important input for use in all stages of food production and agricultural products, for example oil as input in fertilizer, irrigation, crop processing, packaging until transport processing in distributing of agricultural commodities.

A number of empirical studies provide evidence an significant relationship between world oil prices and agricultural commodity prices (Saghaian, 2010; Chen et al., 2010; Esmaeili \& Shokoohi, 2011; Baffes \& Dennis, 2013; Ibrahim, 2015). While another research (Zhang et al, 2010; Nazlioglu \& Soytas, 2011; Fowowe, 2016) found no relationship (neutrality) between oil price and exchange rate to agricultural commodity price. As far as Indonesia is concerned, studies linking crude oil prices and agricultural commodity prices has been examined by Abdlaziz et al (2016) and Pratomo (2016) both in short and long term.

The trend of world oil prices is very fluctuating can be viewed clearly in Figure 1.1. The unstable changes of world oil price can affect the Indonesian economy by impacting prices. As world oil prices rise, it will trigger an increase in prices of petroleum products such as gasoline and other domestic fuels, which driven the cost of production inputs and selling prices of agricultural commodities. 
Considering some selected agricultural commodity prices in Indonesia, such as rice, corn and soybean prices have increased along with rising oil prices (Figure 1.1). However, when oil prices drop dramatically over a certain period, the price of local agricultural commodities does not show a decline in prices. The three types of agricultural commodities are selected based on the Bakhat \& Wurzburg (2013), they said that corn and soybeans are food products that can be converted into biofuel and rice is a staple food that is mostly consumed by the Indonesian population and has an indirect relationship to oil prices.

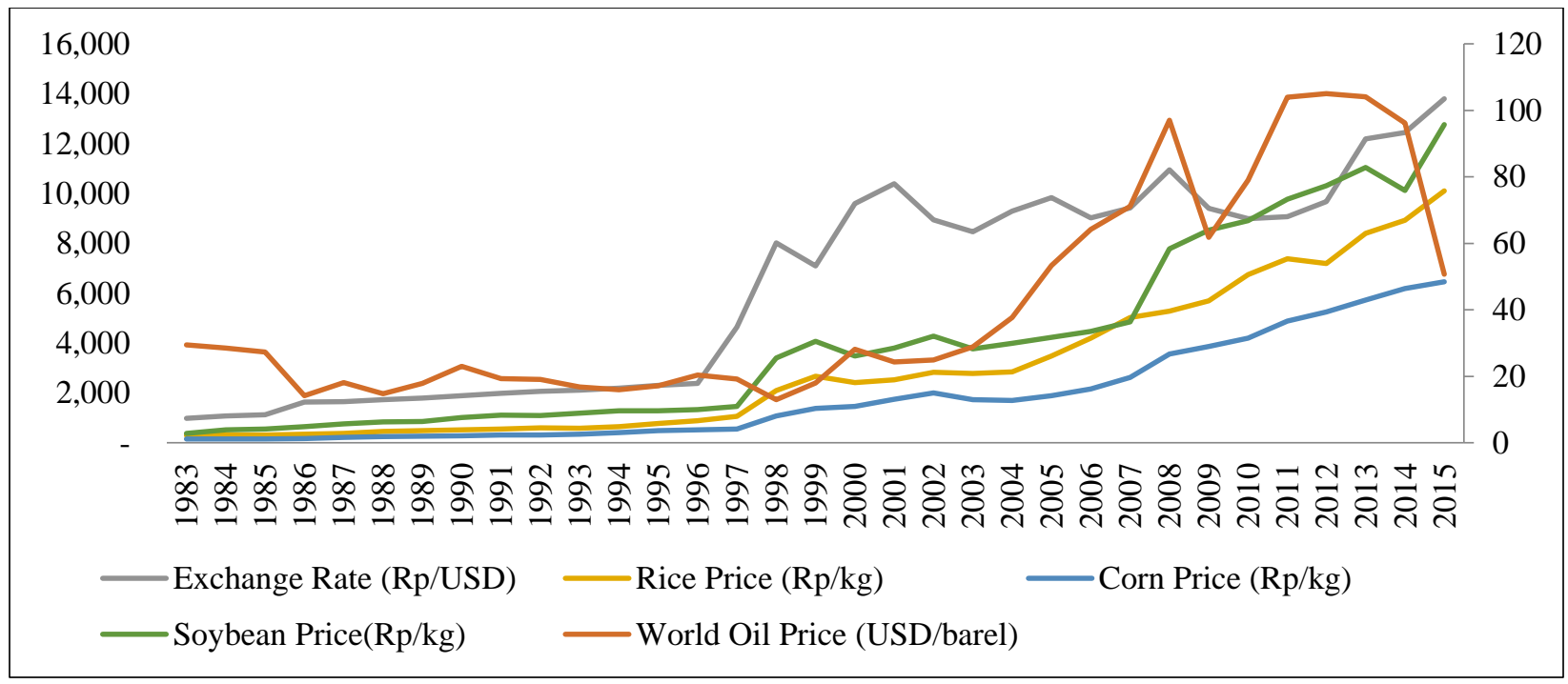

Source : IMF \& Central Bank of Indonesia (2017), Center for Agricultural Data and Information System (2016)

Figure 1.1 World Oil Prices, Rates and Agricultural Commodity Prices, 1983-2015

In addition to world oil prices, exchange rate is also one of the factors that affect agricultural commodity prices. Exchange rate fluctuations can affect domestic prices directly through changes in the prices of imported goods (finished goods or raw materials). In general, when a currency of a country depreciates it will result in higher import prices due to rising marginal costs and also increasing domestic demand so that indirectly will affect the price of domestically produced goods (Hyder and Shah, 2004).

Previous research on the effect of exchange rate on food commodity prices is investigated by Harri et al. (2009) revealed that exchange rates play a role in the linkage of oil prices and prices of agricultural commodities. While Rezitis (2015a) and Jati (2013a) mentioned that the impact of changes in US dollar exchange rate is negative and statistically significant, on the contrary the weakening dollar has a positive effect on agricultural commodity prices shown by Nazlioglu \& Soytas (2012). Even Burakov (2016) found evidence of exchange rates has no significant effect on prices of agricultural commodities in Russia.

Figure 1.2 describes that the rupiah exchange rate against the US dollar from 1983-2016 shows depreciation or decline in the value of currency. Depreciation of exchange rate can be worrying for Indonesia if the rupiah exchange rate continues to weaken against the US dollar, it is understood that energy needs and some food commodities still have to be imported from other countries such as rice and soybeans. This means that the price of agricultural commodities in 
Indonesia will increase when the rupiah depreciates against other currencies and decreases as the rupiah strengthens.

Research on this topic is one of the most important things to examine, the purpose is to understand is to know how the relationship and how much influence the world oil prices and the rupiah exchange rate per US dollar in affecting food commodity prices. In the end it can be found the policies that can be taken to maintain the stability of food commodity associated with world oil price variables and exchange rates and to prevent higher inflation due to the impact of food commodity price fluctuations. Based on this background, it is necessary to analyze the relationship between world oil price and exchange rate to agricultural commodity price in Indonesia by selecting the types of food crops tested that is rice, corn and soybeans.

\section{LITERATUR REVIEW}

In previous studies, a number of techniques or approaches were used to test the relationship of oil prices and exchange rates to agricultural commodity prices. Among these studies, linear regression models such as Vector Autoregression (VAR), Vector Error Correction Model (VECM), cointegration and causality tests have been widely used. Harri et al. (2009) using Johansen Trace Cointegration provided a clear evidence of a long-run equilibrium relationship between oil prices and commodity prices for corn, cotton, and soybeans, but wheat prices are not, and that exchange rates do play a role in the linkage of prices over time.

Saghaian (2010) presents empirical results obtained using VECM and Granger Causality to investigate the relationship between the prices of oil, ethanol, corn, soybeans and wheat. The empirical results showed that there is a strong correlation among oil and commodity prices and that crude oil prices Granger cause corn, soybean and wheat prices. Chen et al. (2010) using Autoregressive Distributed Lag (ARDL) revealed that changes in grain prices (corn, soybeans, and wheat) are strongly influenced by changes in crude oil prices and other grain prices.

Using Principal Component Analysis and Granger Causality, Esmaeili and Shokoohi (2011) found that crude oil prices have an effect on the food production index and consequently have an indirect effect on food prices. Bakhat \& Wurzburg (2013) using Cointegration analysis found an increase in the use of biofuel causes food prices to be associated with crude oil prices, specially food products used to produce biofuels.

Baffes \& Dennis (2013) applied econometric model Reduce Form. The paper concluded that significant contribution of oil price to agricultural prices especially during oil prices are rising sharply. Furthermore, research using the VECM model was also carried out by Jati (2013b) analyzed the price of sugar commodities in sugar-producer countries such as Brazil, India, France and Indonesia. In general can it be concluded that there are negative response of Brazilian, Indian, French sugar price from shock of exchange rate.

Rezitis (2015a) examined the long-term relationship between crude oil prices, US dollar exchange rates, and the prices of thirty selected international agricultural prices and five international fertilizer prices using panel econometric methods with and without unobserved heterogeneous effects. The results indicated that in the long run the impact of crude oil price changes on agricultural prices is positive and significant, while the impact of US dollar exchange rate changes is negative and significant.

Nazlioglu and Soytas (2012) explained the relationship between oil price and 24 world agricultural commodity prices in panel setting : Panel Cointegration and Granger Causality. They 
found strong evidence of transmission from world oil price to agricultural commodity prices, on one side and a positive impact of the weak dollar on food prices on another side.

Different results are found by Zhang et al. (2010) who examined the relationship between fuel prices and food prices using VECM dan Granger Causality. The paper reported that there is not any long run and short-run causality between the fuel (oil, gasoline and ethanol) and agricultural commodity (corn, soybeans, wheat, sugar and rice) prices. And also found a positive effect of sugar prices on oil prices and other agricultural commodities.

This finding is similar to Nazlioglu \& Soytas (2011) using Toda-Yamamoto Causality in the Turkish case, Nazlioglu (2011) found agricultural commodity prices (wheat, corn, cotton, soybean and sunflower) to be neutral to the effects of oil price changes over the long run. And this is in line with the findings of Burakov (2016) using Granger Causality. The results showed that agricultural prices are not particularly sensitive to changes in oil prices and the exchange rate is observed only in case of imported agricultural goods.

Particularly in Indonesia, Pratomo (2016) using Vector Error Correction Model (VECM). The results indicated that in the long run the price of crude oil can affect domestic maize prices, the world prices of rice and wheat as well as indirectly affect the domestic price of wheat. In the short run, crude oil prices can affect domestic rice prices. Nevertheless, this study finds no evidence of the existence of either short term or long term relationships between domestic petroleum prices and domestic prices of all food commodities. Jati (2013a) using Vector Autoregressions (VAR) model, the results showed that a positive response of Indonesian sugar price from shock of the change of oil price.

In addition, some researchers observed the price of agricultural commodities in a nonlinear method. For example Abdlaziz et al. (2016) using Non-Linear Autoregressive Distributed Lag (NARDL) and the results showed evidence of a strong positive relation between oil price increase and food price in both short and long-run in domestic currency for Indonesia. Then oil prices measured in US dollar are also significant.

Fowowe (2016) using Structural Break Cointegration and Nonlinear Causality found that the surging prices of agricultural commodities (maize, sunflower, soybean, oil) in South Africa were not caused by rising oil prices. Ibrahim (2015) applied a similar model in the case of Malaysia, he pointed that there exist a long-run relation between oil price increase and food price in case Malaysia while the long-term oil price reduction and food price is non-existent.

\section{THEORETICAL FRAMEWORK}

\section{Effect of World Oil Prices to Agricultural Commodities Prices}

Gilbert and Mugera (2014) said world oil prices can affect agricultural commodities prices in two different ways. First, crude oil is included in the aggregate production function of primary commodities through the use of various energy-intensive inputs. Second, some food commodities used as an alternative to conventional fossil fuels are one of the factors of the food price spike. Especially corn and soybean crops in the production of ethanol and other vegetable oils for biodiesel production. 


\section{Effect of Exchange Rate to Agricultural Commodities Prices}

Exchange rate movements can affect prices through various transmission channels (Sugeng et al, 2010) include: (1) Direct passthrough, changes in the price of goods. Depreciation increases the import costs directly that importers must bear on the rise in import prices (first round effect). Furthermore, importers selling imported goods to consumers have an alternative to penetrate that price or charge it to consumers in the form of consumer price increase (second round effect); (2) Indirect passthrough can be seen in the shift of marketing orientation from domestic market to international market. Depreciation makes the price of exported goods cheaper thus encourage exports; (3) Inflation expectation, exchange rate depreciation will cause future price increases.

\section{METHODOLOGY AND DATA}

This study employed monthly secondary time-series data on relationships between world oil price, exchange rates and prices of agricultural commodities variables that was sourced from International Monetary Fund (IMF), Center for Agricultural Data and Information System of the Ministry of Agriculture, and Central Bank of Indonesia. The data covered the period January 2010 to June 2017 focusing on rice price, corn price and soybean price in Indonesia.

\section{Model Analysis}

In this research use Vector Error Correction Model (VECM) model. With the VECM method, the researcher can know the short-term behavior of a variable to its long-term due to shock, analyze the reaction of each variable in case of shock, analyze the source of variation of a variable and know the relation of each variable. The VAR / VECM model with $n$ endogenous variables is shown by the following equation (Widarjono, 2007):

$\Delta Y t=\beta_{0}+\beta_{1} \Delta X_{1 t-i}+\beta_{2} \Delta X_{2 t-i}+. .+\beta_{n} \Delta X_{n t-i}+\varepsilon_{t}$

The specification of the VECM model used to analyze the relationship between world oil prices and exchange rate to food commodity prices (rice, corn and soybean) in Indonesia refers to a model developed by Obadi and Korcek (2014). And the authors add rupiah exchange rate per US dollar variable into the model. The VECM model that formed in this study are :

\section{a. Rice Price Equation}

$$
\begin{aligned}
& \Delta C O=\beta_{0}+\beta_{1} \Delta C O_{t-i}+\beta_{2} \Delta E R_{t-i}+\varepsilon_{t} \\
& \Delta E R=\beta_{0}+\beta_{1} \Delta C O_{t-i}+\beta_{2} \Delta E R_{t-i}+\beta_{3} \Delta R P_{t-i}+\varepsilon_{t} \\
& \Delta R P=\beta_{0}+\beta_{1} \Delta C O_{t-i}+\beta_{2} \Delta E R_{t-i}+\beta_{3} \Delta R P_{t-i}+\varepsilon_{t}
\end{aligned}
$$

\section{b. Corn Price Equation}

$$
\begin{aligned}
& \Delta C O=\beta_{0}+\beta_{1} \Delta C O_{t-i}+\beta_{2} \Delta E R_{t-i}+\varepsilon_{t} \\
& \Delta E R=\beta_{0}+\beta_{1} \Delta C O_{t-i}+\beta_{2} \Delta E R_{t-i}+\beta_{3} \Delta C P_{t-i}+\varepsilon_{t} \\
& \Delta C P=\beta_{0}+\beta_{1} \Delta C O_{t-i}+\beta_{2} \Delta E R_{t-i}+\beta_{3} \Delta C P_{t-i}+\varepsilon_{t}
\end{aligned}
$$

$$
\begin{aligned}
& \text { c. Soybean Price Equation } \\
& \Delta C O=\beta_{0}+\beta_{1} \Delta C O_{t-i}+\beta_{2} \Delta E R_{t-i}+\varepsilon_{t} \\
& \Delta E R=\beta_{0}+\beta_{1} \Delta C O_{t-i}+\beta_{2} \Delta E R_{t-i}+\beta_{3} \Delta S P_{t-i}+\varepsilon_{t} \\
& \Delta S Y P=\beta_{0}+\beta_{1} \Delta C O_{t-i}+\beta_{2} \Delta E R_{t-i}+\beta_{3} \Delta S Y P_{t-i}+\varepsilon_{t}
\end{aligned}
$$


Note :

CO is world oil price; ER is Exchange Rate Rp / USD; RP is rice price; CP is corn price; SYP is soybeans price; $\beta_{0}$ is a constant; $\beta_{1}$ to $\beta_{3}$ is regression coefficient; $\Delta$ is first difference; $t$ - is lag of vector; $\varepsilon t$ is residual in period $t$.

\section{EMPIRICAL RESULTS}

Several stages are used in estimating VAR / VECM included stationarity of data test by using Phillips Perron test. Second, optimal lag determination with Akaike Information Criteria (AIC). After optimum lag is obtained then doing cointegration and causality test between variables, followed by with Impulse Response Function (IRF), and Forecast Error Variance Decomposition (FEVD).

\section{Stationarity Test Results}

From the result of stationary test using PP, all variables of world oil price (CO), exchange rate (ER), rice price (RP), corn price (CP) and soybean price (SYP) are not stationary at level I (0) . In order for these variables to be stationary, it is necessary to assume those variables to stationary at first difference level.

Table 1.1.

Stationarity Test

\begin{tabular}{lccccc}
\hline \multirow{2}{*}{ Variable } & \multicolumn{2}{c}{ Statistic Value } & \multicolumn{2}{c}{ Critical Value } & \multirow{2}{*}{ Stationary } \\
\cline { 2 - 5 } & At Level & $\mathbf{1}^{\text {st }}$ Diff & $\mathbf{5 \%}$ & $\mathbf{1 0 \%}$ & \\
\hline LNCO & -5.86 & $-49.51^{*}$ & -21.78 & -18.42 & $I(1)$ \\
LNER & -9.28 & $-95.11^{*}$ & -21.78 & -18.42 & $I(1)$ \\
LNRP & -7.23 & $-31.32^{*}$ & -21.78 & -18.42 & $I(1)$ \\
LNCP & -6.49 & $-61.29^{*}$ & -21.78 & -18.42 & $I(1)$ \\
LNSYP & -2.97 & $-73.18^{*}$ & -21.78 & -18.42 & $I(1)$ \\
\hline
\end{tabular}

Note : ${ }^{*}$ denotes $5 \%$ significance level .

Source: Results of Data Processing, Easyreg (2017)

After data transformation, five variables have been stationary at first difference I (1) at the 5 percent level of significance. It is evidenced from statistical value is greater than critical value and thus the null hypothesis $\mathrm{Ho}$ is rejected and receive $\mathrm{H} 1$. Since there are stationary variables on the same difference or first difference, the cointegration test is conducted further.

\section{Optimal Lag Determination Test Results}

After testing stationerity, next is the optimal lag length test. An optimal lag was selected by minimizing the Akaike Information Criterion (AIC) where lag with the smallest statistical value marked by an asterisk $\left({ }^{*}\right)$. In the test results can be obtained an optimal lag of two for rice price equation, while lag 1 for price equation of corn and soybean prices. Optimal lag determination are presented in Table 1.2. 
Table 1.2.

Optimal Lag Determination Test

\begin{tabular}{cccc}
\hline \multirow{2}{*}{ Lag } & \multicolumn{3}{c}{ Akaike Information Criteria (AIC) } \\
\cline { 2 - 4 } & Rice Price & Corn Price & Soybean Price \\
\hline 1 & -21.218 & $-20.788^{*}$ & $-20.891^{*}$ \\
2 & $-21.333^{*}$ & -20.673 & -20.752 \\
3 & -21.234 & -20.568 & -20.577 \\
4 & -21.147 & -20.577 & -20.440 \\
5 & -20.987 & -20.452 & -20.249 \\
6 & -20.866 & -20.346 & -20.147 \\
7 & -20.797 & -20.266 & -20.039 \\
\hline $\mathbf{p}=$ & $\mathbf{2}$ & $\mathbf{1}$ & $\mathbf{1}$ \\
\hline Source: & Results of Data Processing, Easyreg (2017)
\end{tabular}

\section{Cointegration Test Results}

The result of cointegration test using Johansen Cointegration Test method shows that VECM model used in this research has cointegration at 5 percent confidence level. This can be seen from larger statistics value than 5 percent level. The existence of cointegration indicates that prices tend to move towards the equilibrium relationship in the long-run, in other words world oil price variables and exchange rates greatly affect each agricultural commodity price in the long run.

Table 1.3.

Cointegration Test

\begin{tabular}{c|c|c|c|l}
\hline \multirow{2}{*}{ Equation } & \multirow{2}{*}{$\mathbf{R}$} & \multicolumn{3}{|c}{ Lambda-max Test } \\
\cline { 3 - 5 } & & Statistic & $\mathbf{5 \%}$ & Decision \\
\hline \multirow{4}{*}{ Rice Price } & 0 & 60 & & Tolak $\mathrm{H}_{0}$ \\
& 1 & 36,7 & & Tolak $\mathrm{H}_{0}$ \\
& 2 & 33,2 & \multirow{2}{*}{25,4} & Tolak $\mathrm{H}_{0}$ \\
\cline { 3 - 3 } Corn Price & 0 & 78 & 19,2 & Tolak $\mathrm{H}_{0}$ \\
& 1 & 59 & 12,5 & Tolak $\mathrm{H}_{0}$ \\
& 2 & 37,7 & & Tolak $\mathrm{H}_{0}$ \\
\cline { 2 - 3 } & 0 & 69,3 & & Tolak $\mathrm{H}_{0}$ \\
Soybean Price & 1 & 64,9 & & Tolak $\mathrm{H}_{0}$ \\
& 2 & 37,3 & & Tolak $\mathrm{H}_{0}$ \\
\hline \multirow{4}{*}{ Source: Results of Data Processing, Easyreg (2017) }
\end{tabular}

This finding is in line with Gohin and Chantret (2010) that in the short term, agricultural prices reflect more quasi-fixed production costs of some agricultural production factors such as land and capital. So that high energy prices which means an increase in agricultural production costs will be seen in the medium term or long term. Likewise with the exchange rate that if in the 
long run continues to weaken against the dollar it will have a negative impact on the increase in prices of goods in the country.

\section{Granger Causality Test Result}

Granger causality test is used to see the causality relationship between variables in this study of world oil prices, exchange rates and commodity prices such as rice, corn and soybean prices. If the test results show $\mathrm{H}_{0}$ is rejected, then there is a causal relationship between world oil prices, exchange rate and agricultural commodity prices.

Table 1.4.

Granger Causality Test of Rice Price

\begin{tabular}{ccccc}
\hline Dependent & \multicolumn{4}{c}{ Wald Test } \\
\cline { 2 - 5 } Variable & CO & ER & RP & Decision \\
\hline CO & - & $0,12[0,944]$ & - & Accept $\mathrm{H}_{0}$ \\
ER & $1,86[0,394]$ & - & $0,57[0,750]$ & Accept $\mathrm{H}_{0}$ \\
RP & $14,89[0,000]^{*}$ & $1,91[0,383]$ & - & Reject $\mathrm{H}_{0}(\mathrm{CO} \rightarrow \mathrm{RP})$ \\
\hline
\end{tabular}

Note $:{ }^{*}$ denote a causal relationship at $5 \%$ significance level . Critical Value $5 \%=5.99$; [] = probability value; Lag 2.

Source: Results of Data Processing, Easyreg (2017)

The result of the research using Granger causality test in Table 1.4 shows that there is a unidirectional relationship between world oil price (CO) to rice price (RP). The world oil price variable is statistically significant affect rice price where the Wald test statistic $(14,89)$ is greater than the critical value $(5,99)$ and probability value $(0,000)$ less than 5 percent significance level.at. This result is as expected, existence of unidirectional relationship between world oil prices and agricultural commodities (food) prices.

Exchange rate has no causal relationship to rice price. This can be seen from the Wald test that is below the critical value while the probability value exceeds 0.05 .

In contrast to the previous analysis, relationship of corn prices is analyzed through t-test by comparing t-statistic value with t-table or it can also consider to its probability value. The null hypothesis is rejected if the t-statistic value is greater than the t-table or the probability value is less than $5 \%$ alpha $(\alpha)$ value. From the Granger causality test of corn price, it can be seen that the probability value of the three variables is greater than 0.05 . So that based on the provision of $t-$ test analysis, it can be concluded that there is no pattern of causality relationship either one or two direction between world oil price, exchange rate and corn price. 
Table 1.5.

Granger Causality Test of Corn Price

\begin{tabular}{ccccc}
\hline Dependent & \multicolumn{4}{c}{ t-test } \\
\cline { 2 - 5 } Variable & CO & ER & CP & Decision \\
\hline CO & - & $-0,28[0,777]$ & - & Accept $H_{0}$ \\
ER & $-0,99[0,322]$ & - & $-0,68[0,494]$ & Accept Ho $H_{0}$ \\
CP & $-0,89[0,372]$ & $-1,22[0,220]$ & - & Accept Ho \\
\hline \multicolumn{5}{c}{ Note $:[]=$ probability value; Lag 1. } \\
\multicolumn{5}{c}{ Source: Results of Data Processing, Easyreg (2017) }
\end{tabular}

The Granger causality test for soybean price equation shows similar results with corn price causality test results. In Table 1.6 it is found that the three variables have no causality relationship or direction, this is proved by probability value is above 0,05 .

Table 1.6.

Granger Causality Test of Soybean Price

\begin{tabular}{ccccc}
\hline Dependent & \multicolumn{4}{c}{ t-test } \\
\cline { 2 - 5 } Variable & CO & ER & SYP & Decision \\
\hline CO & - & $-0,28[0,777]$ & - & Accept Ho \\
ER & $-0,90[0,370]$ & - & $-1,10[0,271]$ & Accept Ho $H_{0}$ \\
SYP & $-0,69[0,493]$ & $0,68[0,496]$ & - & Accept Ho $H_{0}$ \\
\hline \multicolumn{4}{c}{ Note : [] = probability value; Lag 1. } \\
\multicolumn{5}{c}{ Source: Results of Data Processing, Easyreg (2017) }
\end{tabular}

\section{Impulse Response Function (IRF) Results}

Impulse Response Function Analysis is used to track the responses of a shock to an endogenous variable on itself or on another endogenous variable in VECM model. This effect can be positive, negatif, or no longer in the short run or long term.

\section{IRF test of World Oil Prices to Agricultural Commodity Prices}

Figure 1.2 s.d 1.4 illustrates the response of food commodity prices (rice, corn and soybeans) to world oil price shocks. Among the three figures that have a significant response are rice prices. The price of rice responds to world oil prices since the first period and is quite significant in second period, but the response is either negatively or contrary to previous theory. That is, rice prices have not increased despite world oil price shocks. This negative response may be related to the Indonesian government's policy of subsidizing fuel oil (BBM).

Jati (2013b) in his research about effect of oil price on Indonesian sugar price, whether the shock from the change of oil price is not positive to the change of sugar price because Indonesian

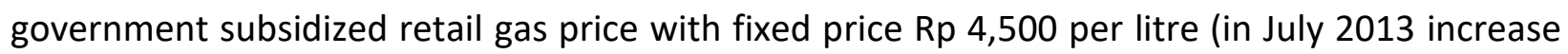

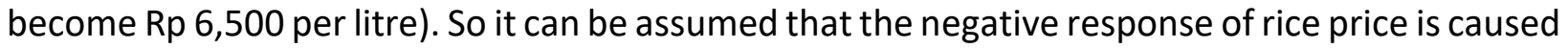
by government subsidy. This is consistent with Ibrahim (2015) in his research in Malaysia said 
that the low oil price pass-through may be attributed to such public policy schemes asadministered prices of essential food items and subsidies as well as adjustment costs.

However, in the 4th month, rice prices increased during shock of world oil prices. The result of this analysis is suspected because the government abolished premium fuel subsidy while diesel fuel was only subsidized Rp 1,000 per litre in line the decline of world oil price at the beginning of 2015. The abolition of fuel subsidy caused domestic fuel price to move following the market price so that the price of fuel increased and decreased easily referring to fluctuating world oil prices. As a result, rice price will rise if world oil prices may rise again in the long run.

Meanwhile, at the time of shocks in world oil prices, the response of corn prices and soybean prices is not significant. Corn and soybean prices were only slightly affected in the first and second months. This is likely due to the absence of further development of alternative energy (biofuel) in Indonesia which uses corn and soybean raw materials. Thus, it does not lead to increased demand and prices for both food commodities despite rising world oil prices. Corn and soybean commodities are still more widely used as food sources.

\section{IRF test of Exchange Rate to Agricultural Commodity Prices}

Based on three Figures 1.5-1.7, it can be seen that shock is caused by exchange rate responded positively to rice price since the first period. In the second period the response was greater and steady until the 20th period. Similarly, soybean prices responded positively to exchange rate from beginning of the first period. In other words when shock of exchange rate occurs, in the first month soybean prices will rise after shock.

In theory, depreciation of exchange rate causes the price of imported commodities become more expensive than domestic commodity prices. Rising prices of imported commodities relative to domestic commodity prices due to depreciation will increase domestic demand. In addition, importers will transfer the burden of rupiah depreciation to consumers. Both of these conditions led to an increase in commodity prices in the country, so that at the beginning of the period of rice and soybean price increases.

However, for IRF test results, the effect of rupiah exchange rate on corn price shows relatively small and negative influence. This is because Indonesia is not tied to the import of corn in relatively large quantities or it means that Indonesia has been able to provide corn from domestic production.

\section{Forecast Error Variance Decomposition (FEVD) Results}

Related to FEVD, this study discusses how the contribution of various variables exists within the scope of research in explaining the variability of each price of agricultural commodities (food) such as rice prices, corn prices and soybean prices.

1. The biggest contribution to rice price (RP) comes from itself. In the first period the contribution of rice prices reached 95 percent. In subsequent period, the role of rice prices continues to decline. As the declining in the role of rice prices, contribution from other variables shows an increase. From the first period of world oil prices and exchange rates contributed 4 percent and 1 percent respectively. Further periods, the contribution of world oil prices in the second period was 16 percent and then increased to 22 percent until the 20th period, while exchange rate from the second to the 20th period was 3 percent. As can be 
seen the price of rice other than influenced by itself, world oil prices also play a role in rice price.

2. The result of variance decomposition test on corn price (CP) is 95 percent influenced by the price of corn itself. The effect is stable until the 20th period. While contribution from other variables may affect variability of corn prices are low, only about 2 percent for world oil prices and 3 percent for exchange rates.

3. Analysis of variance decomposition on soybean price (SYP) at the beginning of the period on itself is quite large at 95 percent and continues until the 20th period. Meanwhile, world oil prices and exchange rates contributed a few to the change in soybean prices, where world oil prices and exchange rates are 1 percent and 4 percent respectively.

\section{CONCLUSIONS}

From the results of analysis and discussion that have been obtained, it can be presented some conclusions are as follows :

1. The prices of three agricultural (food) commodities in Indonesia such as rice, corn and soybean have shown an upward tren during the study period.

2. There is a long-term equilibrium relationship between world oil prices and the rupiah exchange rate per US dollar against the three commodity prices of food.

3. Based on the results of Granger causality, world oil price only affects rice price. This study provides support the hypothesis of relationship from world oil prices to the price of food commodities in one direction. While the exchange rate did not show the pattern of causality relationship either direction or two direction to each agricultural commodity price under study.

4. According to the Impulse Response Function (IRF), the results of the study indicate that the response of rice price to the world oil prices shock causes these variables to decline in the short term and in the long run increases. But the response of corn and soybean prices is not significant.

5. Shock from the Rupiah exchange rate per US dollar caused an increase in agricultural commodities price, especially commodities that are still imported in large quantities such as rice and soybeans. Conversely, the shock of exchange rate on corn prices shows relatively weak and negative responses.

6. Based on Forecast Error Variance Decomposition (FEVD) results, the variability of each food commodity price is determined more by the contribution itself in both the short and long term. The exchange rate contribution plays a role in the range of 3 to 4 percent for each agricultural commodity price. And only to the rice price, contribution of world oil prices reached 22 percent. This is consistent with the significant response of rice price to the shock of world oil prices that can be seen in IRF test and the earlier Granger causality results. 


\section{REFERENCES}

Aye, G. C. (2016). Causality between Oil Price and South Africa's Food Price: Time Varying Approach. International Economics. 69 (3), 189-207.

Baffes, J. \& Allen, D. (2013). Long-Term Drivers of Food Prices. The World Bank Policy Research Work Paper No. 6455.

Bakhat, M. \& Wurzburg, K. (2013). Price Relationship of Crude Oil and Food Commodities. Working Paper. Alcoa Advancing Sustainability Initiative to Research and Leverage Actionable Solutions on Energy and Environmental Economics.

Burakov, D. (2016). Oil Prices, Exchange Rate and Prices for Agricultural Commodities : Empirical Evidence from Russia. Agris Online Papers in Economics and Informatics. 3 (2), 33-47.

Central Bank of Indonesia. (2017). Exchange Rate Rp/USD, http://www.bankindonesia.go.id/ (last accessed 13 Febuari 2017).

Center for Agricultural Data and Information System. (2016). Outlook Jagung 2016. Jakarta : Ministry of Agriculture of Republic Indonesia.

Center for Agricultural Data and Information. (2016). Outlook Kedelai 2016. Jakarta : Ministry of Agriculture of Republic Indonesia.

Center for Agricultural Data and Information. (2016). Outlook Padi 2016. Jakarta : Ministry of Agriculture of Republic Indonesia.

Center for Agricultural Data and Information. (2017). Agricultural Commodity Prices. http://www.pertanian.go.id/ (last accessed 13 Febuari 2017).

Chen, S.T., H.I Kuo \& C.C. Chen (2010). Modelling the Relationship between the Oil Price and Global Food Prices. Applied Energy. 87 (8), 2517-2525.

Esmaeili, A., Shokoohi, Z. (2011). Assessing The Effect of Oil Price on World Food Prices : Application of Principal Component Analysis. Energy Policy. 39 (2), 1022-1025.

FAO, IFAD \& WFP. 2015. The State of Food Insecurity in The World (2015). Meeting the 2015 international hunger targets taking stock of uneven progress. Rome : FAO.

Food and Agriculture Organization. 2017. Food Price Index dan Beberapa Negara Asia, http://www.faostat.org/ (diakses 13 Febuari 2017).

Fowowe, B. (2016). Do Oil Prices Drive Agricultural Commodity Prices? Evidence from South Africa. Energy. 104, 149-157.

Gilbert, C. L. \& Harriet, K. M. (2014). Food Commodity Prices Volatility : The Role of Biofuels. Natural Resources. 5, 200-212.

Gohin A., Chantret, F. (2010). The Long-Run Impact of Energy Prices on World Agricultural Markets : The Role of Macro-Economic Linkages. Energy Policy. 38, 333-339.

Harri, A., L. Nalley \& Hudson, D. (2009). The Relationship between Oil, Exchange Rates, and Commodity Prices. Journal of Agricultural and Applied Economics. 41 (2), 501-510.

Hyder, Z. \& Sardar, S. (2004). Exchange Rate Pass-Through to Domestic Prices in Pakistan. Working Paper. State Bank of Pakistan.

Ibrahim, M. H. (2015). Oil and Food Prices in Malaysia : A Nonlinear ARDL Analysis. Agricultural and Food Economics. 3 (2), 1-14.

International Monetary Fund. (2017). Crude Oil. http://www.data.imf.org/ (last accessed 13 Febuari 2017). 
Jati, K. (2013a). Sugar Price Analysis in Indonesia. International Journal of Social Science and Humanity. 3 (4), 369-374.

Jati, K. (2013b). Sugar Commodity Price Analysis : Examining Sugar Producer Countries. International Journal of Trade, Economics and Finance. 4 (5), 268-295.

Ministry of Commerce. (2016). Dinamika Stabilisasi Harga. Jakarta.

Nazlioglu, S. \& Soytas, U. (2011). World Oil Prices and Agricultural Commodity Prices : Evidence from an Emerging Market. Energy Economics. 33 (3), 488-496.

Nazlioglu, S. \& Soytas, U. (2012). Oil Price, Agricultural Commodity Prices, and the Dollar : A Panel Cointegration and Causality Analysis. Energy Economics. 34 (4), 1098-1104.

Nurhemi, D. (2014). Pemetaan Ketahanan Pangan di Indonesia : Pendekatan TFP dan Indeks Ketahanan Pangan. Working Paper. Bank Indonesia.

Obadi, S. M. \& Matej, K. (2014). Are Food Prices Affected by Crude Oil Price: Causality Investigation. Review Integrative Business and Economic Research. 3 (11), 391-407.

Pratomo, S. (2016). Investigating The Relationship between The Prices Of World Crude Oil And Domestic Food Commodities : Evidence from Indonesia. Thesis. Postgraduate School Bogor Agricultural University Bogor.

Rezitis, A. N. (2015a). Empirical Analysis of Agricultural Commodity Prices, Crude Oil Prices and US Dollar Exchange Rates using Panel Data Econometric Methods. International Journal of Energy Economics and Policy. 5 (3), 851-868.

Saghaian, S. H. (2010). The Impact of the Oil Sector on Commodity Prices : Correlation or Causation?. Journal of Agricultural and Applied Economics. 42 (3), 477-485.

Sugeng, D. (2010). Pengaruh Dinamika Penawaran dan Permintaan Valas Terhadap Nilai Tukar Rupiah dan Kinerja Perekonomian Indonesia. Buletin Ekonomi Moneter dan Perbankan, 312-353.

Sujai, M. (2011). Dampak Kebijakan Fiskal dalam Upaya Stabilisasi Harga Komoditas Pertanian. Analisis Kebijakan Pertanian, 9 (4), 297-312.

Widarjono, A. (2007). Ekonometrika : Teori dan Aplikasi Untuk Ekonomi dan Bisnis. Edisi Kedua. Yogyakarta : Penerbit Ekonisia FE UII.

Zhang, Z., Lohr, L., Escalante, C., Wetzstein, M. (2010). Food Versus Fuel : What Do Prices Tell Us?. Energy Policy, 38, 445-451. 
INTERNATIONAL JOURNAL OF ACADEMIC RESEARCH IN BUSINESS AND SOCIAL SCIENCES Vol. 8, No. 12, Dec, 2018, E-ISSN: 2222-6990 @ 2018 HRMARS
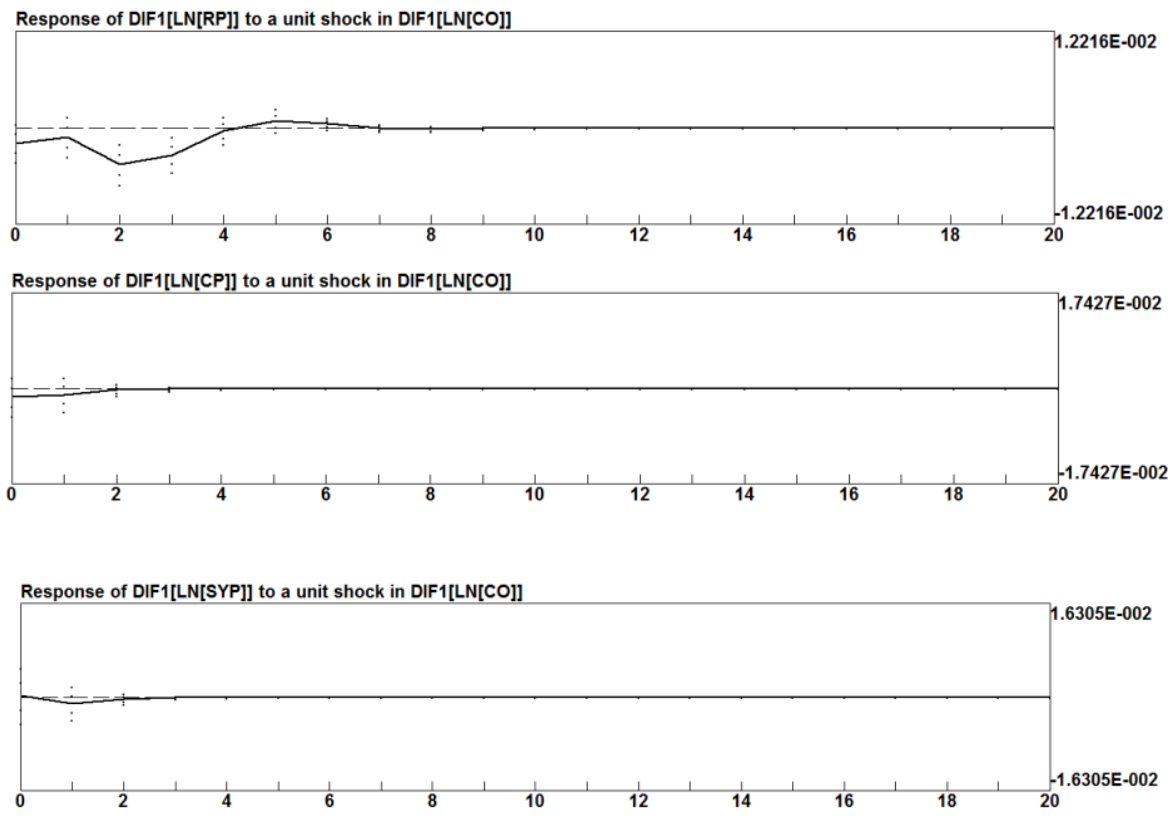

Figure 1.2-1.4 Effect of World Oil Prices Against Agricultural Commodity Prices Sources : Results of Data Processing, Easyreg (2017)
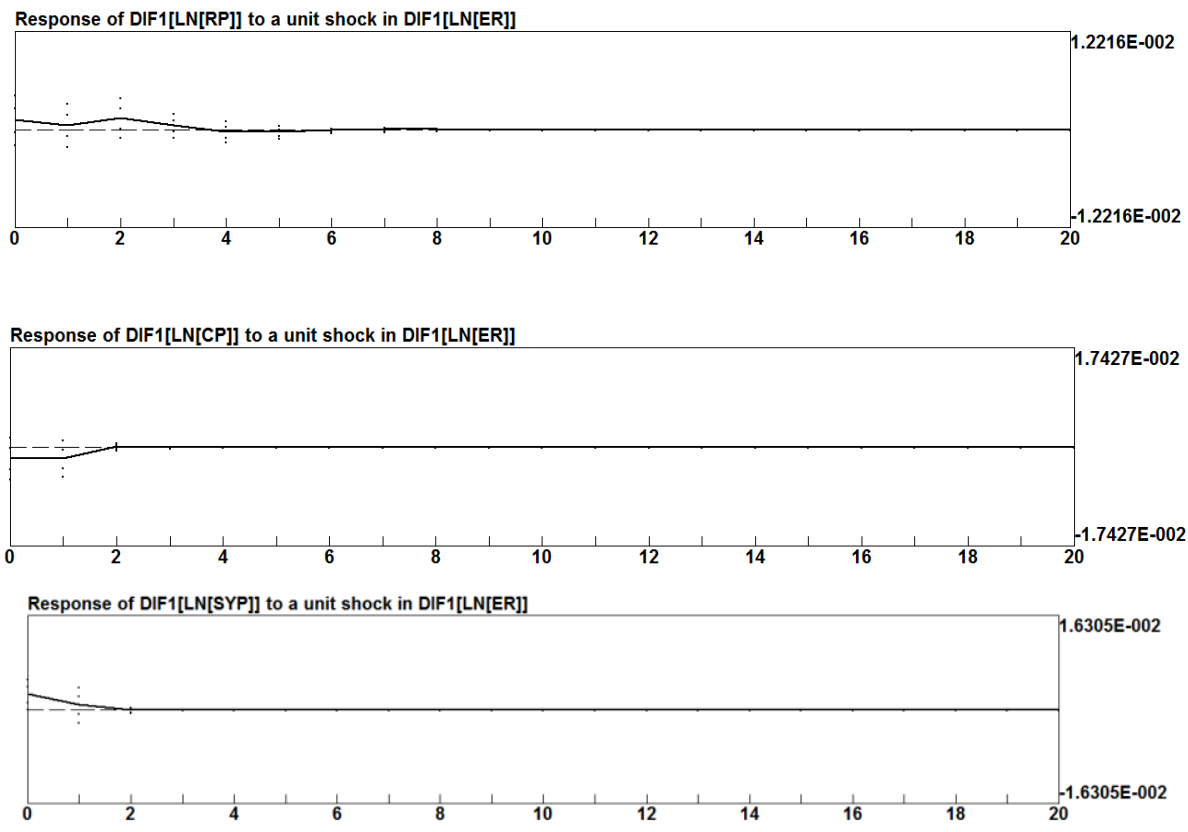

Figure 1.5-1.7 Effect of Exchange Rates Against Agricultural Commodity Prices Source: Results of Data Processing, Easyreg (2017) 